\title{
INNOVATIVE CONSISTENCY IN ORGANISATIONS - BUSINESS PROCESS MANAGEMENT PERSPECTIVE
}

\author{
Michat Flieger*
}

\begin{abstract}
Background. Getting competitive advantage is a process that becomes more and more difficult in nowadays' organisations. Today not only do business organizations compete but also public ones. That makes the search for new ways of effectiveness even more up to date problem. One of the area in which this advantage is built is organisational structures. When it comes to the structures, process management and process organisations are very often introduced. The concept of organizational consistency may be related to eny organization but as process structures are the future of organization the consistency is analysed from process perspective.
\end{abstract}

Research aims. The article is to introduce and operationalize the consistency theory from the perspective of process organizations. This way scholars as well as practitioners will be able to get to know this perspective of harmonization in organisation and use it in practise.

Methodology. To recognize consistency and its nature theoretical discussion takes place in the article. It is based on the literature but mostly comes from the Author's own ideas.

Key findings. In the article the consistency problem is presented as the way to be innovative and to achieve competitive advantage. The article also presents the perspectives and platforms from which the consistency may by analysed. The perspectives as well as their explanations have been introduced in this paper. As the article presents there is a need to operationalize consistency concept deeper so that is is more understandable especially for practice.

Keywords: consistency, process management, consistency platforms, organisational innovations.

\footnotetext{
*Uniwersytet im. Adama Mickiewicza w Poznaniu. E-mail: m.flieger@wp.pl
} 


\section{INTRODUCTION}

In modern organisations the management process constantly changes because of the fact that new trends appear. The trends influence corporate practice significantly when the organisation wants to become competitive and wants to keep and attract new clients. Constant changes concern the external environment in which companies operate as well as their inside. The main external changes are to do with economic and geopolitical conditions but also with a new model of the consumer. New consumers are defined in postmodern theory and they are called postmodern consumers who have some new, specific characteristics to which companies need to adjust. Internal changes are connected mainly with the so-called millennium workers, who require special treatment and with a e turn to nonmaterial values in management. Moreover, the newest technology requires constant applications, which generates organisational effort on a daily basis.

When we take the above into consideration there comes as no surprise that management system transformation is nowadays a constant process. New ideas' implementations take place all the time on each level of management in the organisation and in various areas of business operations. As it concerns all the levels there is a problem of overall planning and coordination, especially from the perspective of strategic management and strategic organisational consistency. Consistency within the organisation is a big issue and it still causes problems as there are no operational models how to become consistent and how to master consistency daily. Thus, there appear specific questions which need to be answered by management scientists. The questions are crucial not only for profound understanding of consistency but also for its practical application. This seems to be one of the most important issues for management theory nowadays. Contemporary managers require some specific support as for the consistency problem, which may be a key to build competitive advantage in a modern way.

Taking into consideration the above matters, the author of the paper tries to drive attention towards the process of corporate consistency construction through providing and detailing the corporate consistency concept, which is the main goal of the paper. The concept consists of given consistency platforms and aspects which are described in details below. Pointing out the corporate consistency concept and its various 
platforms is also one of the main aims of the paper. The concept is a new management theory issue introduced by the author just last year. Another aim of the article is to introduce the corporate consistency model and consistency platforms and pointing out the main aspects in the consistency providing process.

As in today's business there are modern organisational structures implemented the article remains connected with this process (Bober et al., 2004, pp. 25-27). One of the structures that play a more and more important role are process structures, hence, in the article there is also an exemplification of the corporate consistency building process as for process organisation. Connecting consistency with process structures seems to be very important from a theoretical and practical point of view as there is still a lack of knowledge in this matter. As the consistency problem is described in details there needs to be some conclusion considering the future challenges for management science in this area. Such future development directions are presented in the last part of the article.

\section{INNOVATIONS IN THE ORGANISATION}

Innovations in organisations are defined as introducing combinations of new factors, which take place from time to time and considers introducing a new product, new production method, opening new markets for company products, gathering new resources and their suppliers but also new organisation of processes within company. In this article the author focuses on the last area of innovations in organisation (Chomiak-Orsa \& Flieger, 2011a).

Innovations may be considered in two perspectives - in a wide and narrow perspective. The narrow one means the changes in methods of production and in products themselves. The base for such innovations is new knowledge or knowledge unused so far. The wide perspective means each organisational change connected with newly acquired knowledge (Cylwik et al., 2004, p. 168).

The main innovation process is connected with introducing anything new to the organisational practice. According to W. Cellary, innovations may be divided into such categories as:

- product innovations which may be introducing a new product on the market by an organisation or improving an existing 
product as for its characteristics or use (Nowak, 2006, pp. $7-8)$;

- process innovations which are considered to be introducing new or improved production and delivery methods;

- organisational innovations which mean implementing a new organisational structure, new working places or new organisation of external relations with partners;

- marketing innovations which means implementing a new or better marketing method in various marketing areas in the organisation (Cellary, 2011).

There are also some steps which are characteristic to any innovative process in organisations. The first step is appearing of a new idea in any of the above-mentioned areas. The second step means translating the idea into an organisational concept. The third step is the concept's introduction in practice - delivery of a new product, reaching new clients, etc. The last step is checking out the outcome of the innovation through a control or satisfaction survey, which forms the base for looking for new solutions or modifying the existing ones (Chomiak-Orsa \& Flieger, 2011b). What is important, all the steps require extreme management system flexibility, so that the new innovative elements may match smoothly into company operations - this way consistency is sustained.

\section{THE CONSISTENCY CONCEPT BASED ON THE THEORY OF THE SYSTEMS}

Consistency theory is based on the concept created by Ludwig von Bertallanfy called the theory of the systems. Consistency is connected with the fact that when we change one element of the organisation we must probably also change other elements to adjust to the change (Bitkowska, 2009, p. 19). This is one of the most important issues mentioned in the theory of the systems. According to system theory, the change of one element of the system influences other elements and hence the functioning of whole the system changes.

Moreover, when we think about consistency we need to remember that optimisation of one element of the system may have three effects on the whole system. The first one is that the change may improve the systems' effectiveness, the second one - it may deteriorate its 
effectiveness or the last one - it may have no results at all. Thus, taking a point of view represented in the theory of the systems is the base for effective consistency creation.

Considering organisational consistency from a system viewpoint we look at the organisation as at the system (Batko, 2009, pp. 107-116). The conclusions from system theory have a key meaning as it comes to organisational harmonisation and optimisation - which is a core of consistency. When we optimise the organisation by implementing constant changes (as it is in process organisation for example) we need to see it and analyse it as one system and we need to look in different directions, which means searching for possible effects of changes in various areas of the organisation's functioning. Possible effects may also appear in areas which are located far away from each other.

When we analyse consistency and the theory of the systems as such, we come to a conclusion that they are understandable and leave no room for misunderstanding. However, the problems start when we try to operationalise these assumptions in practice, which means when we try to explain in details what consistency actually means. To be able to define consistency in a way that is helpful to managers we need to identify the main areas that need to be changed and show interaction between them. Moreover, we need to show various consistency perspectives, as there are at least a few. Thus, we will be able to identify how possible changes in one area influence other areas. This way, the process of harmonisation, adjusting, and consistency building among different organisational areas will be identified, which will allow to implement it in practice. This will lead to increasing organisational effectiveness (Lichtarski, 2004, p. 42).

An important conclusion resulting from the theory of the systems is also the possibility to see the organisation from the perspective of systems, subsystems and oversystems. It is known that systems consist of subsystems but in the same time systems are the elements of oversystems. Subsystems may join to create systems and systems join to create oversystems. This mechanism was used by the author to construct the concept of consistency which is presented below. When analysing consistency there is a need to be flexible in the organisational perspective - the perspectives change and different viewpoints require different analysing methods. 


\section{CORPORATE CONSISTENCY PERSPECTIVES}

Before consistency perspectives are introduced a crucial remark needs to be made-although the perspectives are universal for any organisation, their internal construction must be adjusted to the strategic level of every organisation: to the mission, vision, strategy, and strategic goals. Since each organisation has a different strategic level, constructing the internal shape of consistency platforms will be different in each case and adjusted appropriately. This approach is necessary and has one big advantage, which is the need to overthink strategic issues first, before further decisions on consistency are made. In many organisations the strategic level is neglected or even abandoned.

\section{Consistency platforms}

When we think about corporate consistency it seems to be a complex topic with a lot of research areas. In fact it is complex so, there is a need to operationalise the level of consistency understanding to make it easier to analyse for managers Consistency platforms are proposed to make analysis possible on an operational level. In this way, managers see clearly what organisational elements to analyse and where consistency is needed.

In the consistency concept proposed in the paper there are three consistency platforms. Each of them should create a consistent system and when this condition is met all the elements of each platform are harmonised and consistent.

The first platform refers to two elements which in theory and practice of management logically fulfil each other - to concepts and methods of management (Jabłoński, 2002, pp. 95-97). Introducing given concepts triggers the need to introduce other concepts so that the first one is complementary supported. Thus, even in the area of concepts there is some consistent subsystem. Furthermore, introducing given management concepts triggers the need to implement given management methods which result from the concepts. When we think about methods, it is not only important to implement them, but also to adjust and accommodate them according to concepts and according to all the methods implemented. So, again here we end up with a consistent subsystem, but this time in the methods' area, which 
is adjusted to the concepts. As we can see, the proposed consistency platforms allow seeking harmonisation of some subsystems, which are internally consistent and moving up on a system level they join in the consistent system.

Platform two consists of two key elements. The first one is the organisational structure and the other one an appropriate style and mechanisms of management in the organisation. In each organisation there is an organisational structure which requires that the style of management which managers prefer as well as the mechanisms they use are appropriately adjusted. Generally speaking organisational structures may be functional structures, process structures (and process-like structures, e.g. virtual) and also hybrid structures which join functional and process ones. Each of the listed kinds of structures differs as for its functioning and requires adjusting the management style and recognising mechanisms which are natural for the structure. When the mechanisms are recognised and understandable for the organisation, they must be actively used by managers of all company levels (Flieger, 2007, pp. 36-37).

The third platform is the platform which integrates the previously analysed platforms with human resource management in the organisation. This platform says that human resources of the company must be adjusted to consistent systems of concepts and methods of management and to the organisational structure and to the style and mechanisms of management. The human capital of the organisation must have some characteristics which are matched to the requirements resulting from previous platforms.

Thus, platform three consists of a consistent subsystem made by two subsubsystems (platform 1 and 2) and a subsystem of human resources (Perechuda, 2000, pp. 924-929). The last one requires special adjustment inside human resource management in the organisation. These adjustments may be in the area of human resource practices and other activities resulting with a given human resource profile. Platform 3 also underlines the key role and the inter-system character of human resources in the organisation, which are the base of efficient and effective functioning of all the other systems mentioned on platform 1 and 2 . 


\section{Process architecture consistency}

When considering any organisational structure there must be a specific consistency among various elements of the structure. Each organisational structure has its own characteristics. However, as mentioned in the introduction to this article, one of the most recent proposals of the structures is a process one, thus this structure will be analysed at this point.

Process structure consistency results straight from process structure nature. There are a few levels of process architecture in each organisation. The first one is the strategic level, which consists of the main and support processes (Bitkowska, 2009, pp. 131-132). Here, the list of processes taking place in an organisation is presented with specific names of the processes. When we are interested if a process consists of sub-processes we need to move to the lower level of the process structure which shows specific sub-processes forming processes from the strategic level. The third level of process structure is a level which shows the sub-processes - the way they are constructed. Here we see specific process operations in a given order with process nests responsible for each operation. The last level of process architecture is the configuration of a given process nest which shows how the operations are performed. Here we can see procedures and instructions for given process operations. All the levels of process structures are shown in Table 1.

Table 1. The process organisation structure and architecture levels

\begin{tabular}{|l|l|}
\hline No. & Process Structure Level \\
\hline 1 & Strategic level - main and support processes \\
\hline 2 & Tactical level - sub-processes forming the main and support processes \\
\hline 3 & Operational level - operations and nests forming sub-processes \\
\hline 4 & $\begin{array}{l}\text { Working level - instructions and procedures used by nests while performing } \\
\text { operations }\end{array}$ \\
\hline
\end{tabular}

Source: own study.

As we can see in Table 1 there are four levels of the process structure which need to be consistent. The consistency here depends on the workers responsible for given levels. The strategic level is organised 
and improved by the process architect and the tactical level is also the responsibility of the process architect. The operational level is the responsibility of process owners and the working level is organised be workers forming process nests. What is crucial here is the need for close cooperation of all the coordinators, especially from the levels which match each other. Hence, the process architect cooperates closely with process owners and process owners cooperate closely with the nests. This way consistency is maintained and continuous improvement takes place (Jon, 2001, p. 50).

\section{Human resource consistency within a process}

Another perspective of sustaining organisational consistency is connected with the human resources consistency within a process. This perspective requires changing the scope of interest into a micro one, where we concentrate on every single process separately. In each process there are specific operations to be made and the operations are usually performed by single workers or their teams (Chomiak-Orsa \& Flieger, 2011c). What must be remembered here is the relation that is the base of each process work. The relation between operation workers is a deliverer/client relation. This relation influences the character of process organisation as a whole.

Considering the above characteristic there is a need to think about consistency in a specific way. Workers performing operations within a process need to communicate effectively, so that the operations can be performed in a way that the internal client requires. It means that before the operation is made, there must be a specific marketing research to be conducted by a worker who simply researches their clients (next process nest). This way navigation tunnels are formed properly and the process is formed in an appropriate way. The mechanism is shown in Figure 1.

As we can see in Figure 1 there is constant cooperation between process nests which makes the process structures effective, flexible, and client oriented. This cooperation relies mostly on an effective communication process. Communication within a process requires a kind of understanding between nests-partners. Such understanding results from consistent characteristics of workers who form the nests. These characteristics should be complementary, so that a synergy effect can be reached. 


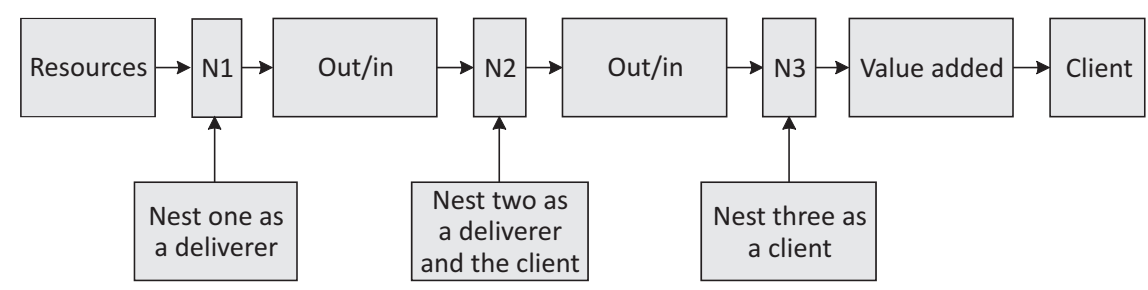

Figure 1. Relations within a process

Source: own study.

What is especially important in such mechanisms is feedback that enables the nests effective establishment of navigation tunnels. The feedback is gained from inter-process clients through specific marketing research made by nests/deliverers. When the nests know exactly what is expected from them they may take productions steps accordingly and match the needs of nests/clients.

Another aspect to be mentioned here is communication between nests in a process and process owners. Owners of processes mostly navigate the nests through mentoring and coaching and effective monitoring of process operations. To be able to get the data they must be matched to human resources forming the nests, so that the communication runs smoothly. It is also important that process owners have the required management style which enables participation, communication, and effective motivation of workers.

The above mentioned intra-process dependencies show clearly where the consistency must be reached. We can call the perspectives intra-process consistency platforms. When managers see and understand consistency through the platforms it is easier for them to create consistency on a micro scale - within a process. They may analyse consistency vertically (process owners - nests) and linearly (nest - nest). Both perspectives are equally important for processes to be effective and consistency must be reached on both platforms simultaneously.

\section{Goals consistency}

Another platform of consistency formed by analysing perspective is connected with organisational goals. In process organisations, consistency concerns two things: the first is connected with consistency 
between functional and process goals and the other with goals of processes and strategy of the whole organisation.

The first consistency platform concerns most process organisations nowadays as process structures are usually hybrid, where functional structures work along with process ones. In such organisations there is a question how to build a consistent system of organisational goals. The problem is that functions and functional workers have their own goals, but at the same time they are a part of processes where they form process nests with other goals. Moreover, organisational functions as such have their own goals and processes do as well. Thus, there is a need to coordinate goals of workers (functional and process) and goals of functions and processes. In each perspective there must be consistency which in this area is very difficult to reach. The difficulty here lies in the number of goals that need to be coordinated. It is a complex task to analyse and coordinate the goals, but at the same time it is necessary because only then do the workers go in the same direction realising their functional and process goals.

Another perspective in the goal topic is consistency of process goals with strategic goals of the company. Realising a lot of processes at the same time and concentrating on their modelling, measuring, and improvement, it may be difficult to see a wider picture in the organisation. The wider picture is connected with the strategic level of the company. What must be remembered here is that processes are not separate beings in the organisation and even when they work perfectly there is a question if they are incorporated in company strategy. Such perspective gives another platform of consistency analysis from managers in any organisation.

\section{CONCLUSIONS}

In today's world organisations need to become innovative in various areas of their operations. Flexibility seems to be one of the main goals to be reached when considering an innovative approach. It must be supported with effectiveness and efficiency. To meet these goals there is a process perspective and process structure that may be implemented. In this way organisations become more consumer-sensitive and may win competitive advantage over their competitors. 
This kind of innovative organisational structures require an ongoing analysis not only of a constant improvement of the structures, but also of the consistency of the whole organisation. The consistency problem in process organisations is something that is not present in the literature of the subject, which makes the topic even more urgent.

Consistency can be reached by looking into the organisation through specific perspectives called consistency platforms. Building consistency requires focusing on each platform separately and then, according to the theory of the systems, matching platforms to one another. This way a profound analysis is possible and managers eliminate the risk of missing important areas which need to be harmonised.

The problem in management literature is that there are no specific tools to measure consistency. Also consistency awareness among managers as well as in the literature almost does not exist. Thus, there is a need to develop the topic in a theoretical sphere as well as expanding managers' knowledge in practice. There still seems to be a lot to be done and that is a challenge which management scientists need to meet. This will enable organisations to increase their competitiveness and meet clients' requirements more effectively.

\section{REFERENCES}

Batko, R. (2009). Zarzadzanie jakościa w urzędach gminy. Kraków: Wydawnictwo Uniwersytetu Jagiellońskiego.

Bitkowska, A. (2009). Zarzadzanie procesami biznesowymi w przedsiębiorstwie. Warszawa: Vizja Press.

Blair, M.M. (2004). Reforming Corporate Governance: What History Can Teach Us. Berkeley Bus.

Brackett, E. Why Consistency is Important? Visible Logic. http://www.visiblelogic. com/blog/2009/04/why-consistency-is-so-important-to-branding/ (access: 6.10.2016).

Bober, J., Mazur, S., Turowski, B. \& Zawicki, M. (2004). Rozwój instytucjonalny. Kraków: Małopolska Szkoła Administracji Publicznej w Krakowie.

Bober, J., Turowski, B., Zawicki, M. \& Mazur, S. (2009). Analiza instytucjonalna urzędu gminy. Kraków: Małopolska Szkoła Administracji Publicznej Akademii Ekonomicznej w Krakowie.

Cellary, W. (2011). Innowacyjność i nauka to nie to samo, czyli jakiej innowacyjności potrzeba $w$ Polsce? Konferencja inaugurująca projekt „Przedsiębiorczy doktorant - inwestycja w innowacyjny rozwój regionu”, Wrocław. 
Chomiak-Orsa, I. \& Flieger, M. (2011a). Computerization as the Improvement of Processes in Local Governments. In: J. Korczak J. (ed.), Advanced Information Technologies for Management. Zeszyty Naukowe Uniwersytetu Ekonomicznego we Wrocławiu.

Chomiak-Orsa, I. \& Flieger, M. (2011b). Inżynieria procesów zarządzania na przykładzie wybranych gmin w Wielkopolsce. In: J. Gołuchowski (ed.), Zeszyty Naukowe Uniwersytetu Ekonomicznego w Katowicach z serii „Studia Ekonomiczne”, Katowice.

Chomiak-Orsa, I. \& Flieger, M. (2011c). Evaluation methods in effective ICT projects implementation. In: L. Maciaszek (ed.), Business Informatics. Zeszyty Naukowe Uniwersytetu Ekonomicznego we Wrocławiu.

Coolidge, R., Corporate Consistency. Executive Blueprint. http://www.executiveblueprints.com/tips/080503_corporateconsistency.htm (access: 6.10.2016).

Cronqvist, H., Makhija, A. \& Yonker, S. (2012). Behavioral consistency in corporate finance: CEO personal and corporate leverage. Journal of Financial Economics, 103(1).

Cylwik, A. et al. (2004), Leksykon zarzadzania. Warszawa: Wydawnictwo Difin.

Flieger, M. (2007). Od administrowania do zarządzania publicznego - transformacja stanowiąca warunek efektywnego zarządzania gminą oraz przedsiębiorstwami sektora publicznego. Prace Naukowe Akademii Ekonomicznej we Wroctawiu, 1184.

Jabłoński, A. (2002). Anglosaska koncepcja nowej administracji publicznej. In: A. Ferens, I. Macek (eds.), Administracja i polityka: administracja publiczna w procesie przemian. Wrocław: Wydawnictwo Uniwersytetu Wrocławskiego.

Jon, P. (2001). Local Governance In Western Europe. London: Sage Publications.

Lichtarski, J. (2004). O relacji między podejściem funkcjonalnym i procesowym w zarządzaniu. In: M. Romabowska \& M. Trocki (eds.), Podejście procesowe w zarzqdzaniu, t. 1, AGH, Warszawa.

Nowak, J. (2006). Modernizacja lokalnej administracji publicznej a rozwój lokalny. Poznań: Wydawnictwo Akademii Ekonomicznej w Poznaniu.

Perechuda, K. (2000). Zarzqdzanie przedsiębiorstwem przyszłości. Warszawa: Agencja Wydawnicza Placet.

Stiglitz, J. (2004). Ekonomia sektora publicznego. Warszawa: Wydawnictwo Naukowe PWN. 


\section{INNOWACYJNA SPÓJNOŚĆ W ORGANIZACJACH - PERSPEKTYWA BPM}

\section{Abstrakt}

Tło badań. Współczesne organizacje zmuszone są do poszukiwania nowych rozwiązań organizacyjnych w celu kształtowania skutecznej przewagi konkurencyjnej. Ten fakt powoduje, że coraz częściej sięgają po innowacyjne rozwiązania organizacyjne o charakterze kompleksowym.

Cel badań. W artykule przedstawiono zarządzanie procesowe oraz struktury procesowe jako te, które wymagają podjęcia szeregu działań komplementarnych związanych z budowaniem spójności organizacyjnej. Zdefiniowano pojęcie spójności organizacyjnej, która warunkuje efektywne i skuteczne funkcjonowanie organizacji. Opisano także platformy osiagania spójności organizacyjnej.

Metodologia. Artykuł prezentuje indywidualne propozycje autora w zakresie koncepcji spójności i opiera się na studiach dotyczących funkcjonowania współczesnych organizacji.

Kluczowe wnioski. Zarówno kwestia spójności w aspekcie rozwiązań innowacyjnych, jak i szczegółowy opis wspomnianych platform wymagaja dalszych prac uszczegóławiających.

Słowa kluczowe: spójność organizacyjna, organizacja procesowa, płaszczyzny spójności. 